\title{
Self-compassion dan Subjective Well-being Remaja Tunadaksa
}

\author{
Ulifa Rahma, Rekyan Puspitasari \\ Prodi Psikologi, Universitas Brawijaya, Malang, Indonesia \\ e-mail: ulifa.rahma@ub.ac.id
}

\begin{abstract}
Adolescents with physical disability are adolescents whose have body abnormalities in their structure or function which can interfere with their activities as normal teenagers. The psychological impact suffered by adolescents with physical disability such as low self-esteem, anxiety, frustration, withdrawal from society and apathy. Those conditions can reduce the level of subjective well-being and to improve there is internal factors, self-compassion. This research aims to examine the relationship between self-compassion and subjective well-being of adolescents with physical disability. This research used quantitative correlational with 140 participants. The results shows that there is a significant relationship self-compassion toward subjective well-being. Relationships have a positive direction, when self-compassion increased, subjective wellbeing also higher in adolescent with physical disability and vice versa.
\end{abstract}

Keywords: self-compassion, subjective well-being, adolescents, physical disability

\begin{abstract}
Abstrak
Remaja tunadaksa merupakan remaja dengan kelainan tubuh dalam struktur ataupun fungsi yang membatasi dirinya untuk beraktivitas layaknya remaja normal. Remaja tunadaksa dapat mengalami dampak psikologis yaitu rendah diri, cemas, frustrasi, menarik diri secara sosial dan memiliki sikap apatis. Kondisi tersebut dapat menurunkan tingkat subjective well-being dan untuk meningkatkannya terdapat faktor internal yaitu self-compassion. Penelitian ini bertujuan mengetahui keterkaitan self-compassion dengan subjective well-being remaja tunadaksa. Metode penelitian menggunakan kuantitatif korelasional dengan jumlah sampel sebanyak 140 orang. Hasil penelitian menunjukkan terdapat hubungan signifikan self-compassion dengan subjective well-being. Hubungan memiliki arah positif, ini bermakna bahwa semakin meningkatnya selfcompassion, akan meningkatkan subjective well-being remaja tunadaksa ataupun sebaliknya.
\end{abstract}

Kata Kunci: self-compassion, subjective well-being, remaja, tunadaksa

\section{Pendahuluan}

Santrock (2014) mengartikan remaja sebagai individu yang berusia 10 hingga 13 tahun dan berakhir antara usia 18 hingga 22 tahun, dimana usia tersebut adalah masa transisi masa anak dengan dewasa dan terdapat perubahan kognitif, biologis, emosional maupun sosial. Remaja kerap kali dituntut untuk melakukan berbagai aktivitas sesuai dengan peran sosialnya sehingga mereka diharapkan untuk selalu produktif.

Remaja yang produktif membutuhkan kondisi fisik yang optimal untuk melakukan kegiatan sehari-hari, menjalin relasi, bersosialisasi dengan sesama, mempersiapkan karier di masa yang akan datang (Santrock, 2014). Namun tidak semua remaja dapat melakukan aktivitas dan tugas-tugas perkembangannya karena kondisi kekurangan pada anggota dan fungsi tubuh, seperti yang dialami oleh remaja tunadaksa.

Direktorat Bina Kesehatan Anak (2014) menjelaskan bahwa penyandang tunadaksa merupakan istilah untuk individu yang mempunyai gangguan dalam pergerakan disebabkan oleh kelainan neuromuscular dan struktur dari tulang yang berbeda, baik itu karena bawaan sejak lahir maupun akibat dari kecelakaan. Menurut Atmaja (2017) individu yang mengalami ketidakmampuan dalam menggunakan fungsi anggota tubuhnya 
secara normal karena penyakit, bawaan, atau pertumbuhan badan yang kurang sempurna sehingga perlu layanan khusus dalam melakukan aktivitas sehari-hari disebut dengan individu penyandang tunadaksa.

Data yang telah dihimpun Badan Pusat Statistik pada tahun 2009, jumlah rincian tunadaksa sebanyak 717.789 jiwa (BPS Susenas RI, 2009 dalam Aziz, 2014). Pada tahun 2010 jumlah penyandang tunadaksa meningkat sebanyak 1.852.866 (Poerwanti, 2017). Hal ini menunjukkan bahwa setiap tahun semakin meningkat jumlah penyandang tunadaksa di Indonesia.

Penelitian Aminzadeh dkk. (2018) memaparkan, individu tunadaksa memiliki subjective well-being yang rendah karena keterbatasan fisik yang dimilikinya. Keterbatasan fisik yang dapat menghambat aktivitas remaja penyandang tunadaksa akan mengakibatkan banyak dampak bagi penyandang tunadaksa termasuk dampak psikologis berupa timbulnya perasaan malu, sedih, kecewa, putus asa, hingga depresi (Mangunsong, 2011). Dampak psikologis yang sifatnya negatif jika dirasakan oleh seseorang secara terusmenerus dapat membuat individu tersebut merasa bahwa dirinya serba kekurangan hingga akhirnya menimbulkan rendahnya subjective well-being.

Diener dkk. (2005) menyebutkan bahwa subjective well-being merupakan hasil evaluasi individu dari aspek kognitif yaitu kepuasan hidup maupun dari aspek afektif baik secara positif atau negatif mengenai kehidupannya. Diener dkk. (2005) mengemukakan terdapat tiga aspek yang membentuk subjective well-being, diantaranya afek negatif berupa emosi tidak disukai individu sebagai respon negatif terhadap kehidupan maupun peristiwa buruk yang dialami, afek positif berupa emosi yang dirasakan dan suasana hati yang menyenangkan, kepuasan hidup berupa penilaian dari segi kognitif individu berdasarkan perbandingan keadaan yang sekarang dialami individu dengan standar yang diinginkan.

Subjective well-being bisa dialami oleh setiap orang, termasuk remaja tunadaksa. Namun remaja penyandang tunadaksa hanya sedikit yang merasakan subjective well-being, biasanya remaja tersebut akan tersingkir dari hubungan sosial dengan masyarakat di sekitarnya karena pandangan negatif masyarakat kepada penyandang tunadaksa. Tersingkirnya dari pergaulan membuat remaja tunadaksa menjadi minder, rendah diri, merasa tidak berguna dan tidak pernah berperan aktif setiap ada kegiatan di masyarakat. Fakta tersebut menunjukkan bahwa orang yang menderita tunadaksa mengalami masalah mengenai dirinya akibat persepsi negatif dari masyarakat sehingga menurunkan subjective well-being (Al-Karimah, 2018).

Al-Karimah (2018) mengungkapkan bahwa penyandang tunadaksa merasa bahagia dan sejahtera saat mereka dapat mencukupi kebutuhan hidupnya sendiri atau dapat dikatakan tidak bergantung pada orang lain. Hal lain yang diungkapkan penyandang tunadaksa adalah merasa dirinya sejahtera saat mereka tidak merasa minder, percaya diri akan keadaan fisik mereka, tidak khawatir akan lingkungan di sekitar mereka atau lingkungan baru yang tidak dapat menerima kondisi keterbatasan mereka. Adapun mengenai perasaan tidak menyenangkan yang mereka rasakan, contohnya adalah saat merasa belum puas dengan apa yang sudah mereka capai selama ini, belum meraih cita-cita yang diinginkan, munculnya rasa kurang percaya diri karena kekurangan fisik, dan adanya kekhawatiran akan tidak diterimanya di lingkungan baru (Al-Karimah, 2018).

Melihat adanya individu dengan subjective well-being rendah maka perlu meninjau peran dari self-compassion untuk meningkatkan subjective well-being. Bluth dan Blanton (2015) menjelaskan selfcompassion dan well-being memiliki hubungan positif pada remaja. Ge dkk. (2019) memaparkan individu dengan self- 
compassion tinggi cenderung menghadapi kekurangan mereka sendiri dengan sikap yang ramah dan hangat. Sikap ini dapat memengaruhi kondisi kognitif dan emosi individu, meningkatkan pengalaman positif individu dan dapat mengurangi pengalaman emosional negatif. Ini selanjutnya dapat meningkatkan subjective well-being individu. Self-compassion memiliki peran fasilitator dalam proses mencapai cita-cita yang ingin dicapai individu dengan cara mengurangi pengaruh emosional negatif akibat kegagalan, self-compassion juga berperan dalam meningkatkan sisi positif yaitu optimisme (Zessin dkk., 2015).

Menurut Zessin dkk.

keterkaitan well-being dan self-compassion adalah bahwa well-being merupakan suatu konsekuensi yang akan didapat dalam mencapai suatu tujuan yang diinginkan, sedangkan self-compassion berperan sebagai fasilitator dalam proses mencapai tujuan tersebut dengan cara mengurangi pengaruh emosional negatif yang hadir akibat adanya kegagalan dan berperan dalam memengaruhi penetapan tujuan dari sisi yang positif.

Self-compassion sendiri diartikan sebagai sikap yang terbuka, peduli, dan baik terhadap diri sendiri saat menghadapi permasalahan, penderitaan, kegagalan dengan tidak menghakimi kekurangan dan ketidaksempurnaan dan mengakui bahwa segala yang telah dialaminya merupakan bagian dari pengalaman yang pasti dialami individu lain secara umum dan normal (Neff, 2015). Ciri individu dengan tingginya self-compassion dapat ditunjukkan dengan kemampuan untuk menerima apa yang menjadi kelebihan maupun kekurangan diri, menerima maupun memaafkan kegagalan karena kegagalan adalah hal yang lumrah, sadar akan segala yang ada bergantung satu dengan yang lain. Sedangkan individu yang memiliki selfcompassion rendah memiliki ciri sering menyalahkan diri sendiri, takut dan selalu cemas akan kegagalan, hingga pesimis untuk masa depannya sendiri (Neff, 2015).
Mengelola self-compassion yang baik melibatkan kebutuhan akan mengelola kesehatan fisik dan psikis sehingga subjective well-being individu naik dan mampu meningkatkan insight dalam membawa perubahan bagi dirinya dan kehidupannya menjadi lebih baik lagi (Zessin dkk., 2015). Tentunya selfcompassion yang baik dan tinggi, jika dimiliki oleh remaja tunadaksa akan memberikan dampak yang baik dalam hal menerima diri sendiri dan menghadapi segala tantangan dengan segala kemampuan yang dimilikinya agar subjective well-being juga meningkat.

Penelitian yang dilakukan oleh Ramawidjaya dan Sartika (2016) pada atlet tunadaksa menjelaskan bahwa banyak tunadaksa yang memiliki self-compassion rendah dimana mereka memiliki pandangan negatif dengan kondisi fisik yang dimiliki dan rendahnya penerimaan diri sehingga merasa cemas, frustrasi, bersikap apatis. Ada pula tunadaksa yang memiliki selfcompassion tinggi terhadap keterbatasan fisik yang dimiliki dan mengubahnya menjadi prestasi. Hal ini karena remaja tunadaksa telah memiliki pemikiran terbuka dan sadar untuk lebih menyayangi dirinya sendiri. Berdasarkan uraian di atas diketahui bahwa terdapat fenomena mengenai rendahnya subjective well-being pada remaja tunadaksa. Agar individu memiliki subjective well-being maka diperlukan self-compassion yang akan berpengaruh pada kesuksesan kehidupannya dalam menghadapi tantangan. Namun penelitian yang membahas secara langsung mengenai kaitan antara self-compassion dengan subjective well-being remaja penyandang tunadaksa masih belum diteliti sehingga peneliti tertarik mengangkat tema tersebut, yang bertujuan untuk mengetahui keterkaitan self-compassion dengan subjective well-being remaja tunadaksa. 


\section{Metode Penelitian}

Pendekatan penelitian menggunakan kuantitatif dengan desain korelasional. Desain ini bertujuan mengukur semua variabel yang saling berhubungan satu sama lain, self-compassion merupakan variabel bebas dan variabel terikatnya adalah subjective well-being.

Teknik non-probability sampling digunakan untuk mengambil sampel, dengan sepesifikasi accidental sampling sebagai teknik dalam menentukan sampel penelitian dari setiap individu yang ditemui peneliti di suatu tempat secara kebetulan yang sesuai dengan konteks penelitian (Sugiyono, 2017). Jumlah sampel dari penelitian ditentukan menggunakan aplikasi G*Power 3.0.10 dengan alpha error probability .05; effect size .3 ; dan power .95 sehingga dihasilkan sampel untuk penelitian minimal berjumlah 134 , namun peneliti menggunakan sampel berjumlah 140 remaja tunadaksa di Kota Malang.

Variabel self-compassion diukur menggunakan skala self-compassion milik Dewi dan Hidayati (2015). Alasan menggunakan skala ini karena dapat digunakan secara umum dan memiliki reliabilitas yang tinggi yaitu .877 , di mana terdapat tiga dimensi yaitu self kindness, common humanity dan mindfulness yang mengacu pada dimensi self-compassion menurut Neff (2013, dalam Barnard \& Curry, 2011). Dari 24 item yang ada, hasil analisis item menunjukkan 15 item terpakai (.444 - .894) dan sisanya 9 item tidak terpakai.

Alat ukur variabel subjective wellbeing, peneliti mengadaptasi skala subjective well-being milik Fakhrunnisak dan Qudsyi (2015) sebagai hasil adaptasi dari alat ukur yang digunakan oleh Diener dkk. (2009) yaitu Scale of Positive and Negative Experience (SPANE). Alasan menggunakan skala ini karena dapat digunakan secara umum dan memiliki reliabilitas yang tinggi yaitu .834. Skala subjective well-being memiliki dimensi kognitif (kepuasan hidup) maupun afektif (kebahagiaan) dengan masing-masing afek positif dan negatif dengan mengacu pada aspek-aspek subjective well-being Diener dkk. (2002). Dari 15 item yang terdapat pada alat ukur, hasil analisis item menunjukkan 8 item terpakai $(.336-.836)$ dan sisanya 7 item tidak terpakai.

Uji validitas yang digunakan adalah validitas tampang maupun logis. Validitas tampang adalah penerimaan dari responden mengenai skala penelitian (Azwar, 2014). Untuk uji validitas logis merupakan penilaian mengenai kelayakan isi item dari suatu skala alat ukur yang dilakukan oleh panel ahli, yang nantinya menghasilkan validitas logis atau tinggi rendahnya kesepakatan dari para ahli yang menilai skala tersebut (Azwar, 2014). Expert judgement untuk menilai item dari skala yang telah dibuat, dilakukan oleh dua orang ahli Psikologi Pendidikan yang memiliki kompetensi terkait disabilitas. Selain itu remaja tunadaksa diminta untuk menilai sejauhmana item skala mudah dipahami atau tidak. Hasilnya item-item pernyataan dapat dipahami dan tidak ada perubahan dari pernyataan-pernyataan dalam skala yang digunakan.

Uji reliabilitas dilakukan kembali apakah item ini reliabel untuk diberikan kepada remaja tunadaksa, menggunakan teknik Cronbach's Alpha. Nilai koefisien alpha untuk skala self-compassion sebesar .953 (reliabilitas sangat tinggi) dan skala subjective well-being memiliki koefisien alpha 847 (reliabilitas sangat tinggi). Analisis data dilakukan dengan uji hipotesis menggunakan korelasi Product Moment Pearson.

\section{Hasil Penelitian dan Pembahasan}

Berdasarkan hasil uji normalitas, diketahui bahwa data berdistribusi normal, untuk self-compassion memiliki signifikansi sebesar .457>.05, demikian pula subjective well-being memiliki signifikansi .292> .05. 
Uji hipotesis dengan taraf signifikansi $5 \%$ (.05), hasil uji hipotesis menunjukkan nilai korelasi (r) sebesar .741 dengan signifikansi .000. Nilai r .741 yang semakin mendekati 1 maka menunjukkan semakin kuatnya korelasi antara self-compassion dengan subjective well-being. Hubungan antar variabel bersifat positif karena nilai $r$ tersebut positif. Korelasi positif menunjukkan bahwa dengan meningkatnya self-compassion remaja tunadaksa, maka semakin meningkat pula subjective wellbeing mereka.

Hasil uji hipotesis didukung oleh perhitungan skor secara hipotetik dengan 3 kategori yaitu: rendah, sedang dan tinggi yang mengacu pada skor mean dan standar deviasi hipotetik. Hasil menunjukkan tidak terdapat subjek yang termasuk ke dalam kategori rendah $(0 \%)$, baik variabel selfcompassion maupun variabel subjective well-being. Pada variabel self-compassion, sebanyak 63 subjek $(45 \%)$ termasuk kategori sedang dan 77 subjek (55\%) kategori tinggi. Adapun pada variabel subjective well-being, sebanyak 56 subjek (40\%) termasuk kategori sedang dan 84 subjek (60\%) kategori tinggi.

Ratnasari dan Sumiati (2017) menunjukkan bahwa adanya kaitan selfcompassion dengan subjective well-being dengan arah positif. Memiliki kekurangan dan mengalami kegagalan bukanlah hal yang mudah diterima, namun dengan adanya self-compassion individu mampu untuk lebih cepat memahami, dan menerima kejadian hingga memunculkan insight yang lebih baik lagi. Ge dkk. (2019) menjelaskan bahwa self-compassion dapat menyesuaikan dampak psikologis dari tekanan hidup pada individu, meningkatkan kemampuan untuk mengendalikan emosi negatif, dan membuat pengalaman emosional dan evaluasi subyektif mereka lebih positif, sehingga dapat mempertahankan subjective well-being yang tinggi. Jeon dkk. (2016) juga melaporkan bahwa terdapat kaitan positif self-compassion dengan subjective well- being individu karena self-compassion membantu individu untuk menilai kegagalan mereka dari sudut pandang yang lebih positif, memaknai setiap kejadian dengan emosi positif, dan menurunkan perasaan negatif. Zessin dkk. (2015) menjelaskan bahwa self-compassion menggambarkan sikap positif dan perhatian seseorang terhadap dirinya sendiri dalam menghadapi kegagalan dan kekurangan individu. Sebagai hasil dari sikap peduli ini, individu yang memiliki self-compassion diasumsikan mengalami subjective wellbeing yang lebih tinggi.

Cug (2015) menjelaskan selfcompassion mengarahkan individu untuk meningkatkan subjective well-being dimana individu merasa diperhatikan, terhubung, dan tenang secara emosional. Lebih jauh lagi, self-compassion berfungsi untuk mengatur emosi dan mengubah perasaan negatif menjadi perasaan positif. Philips dan Ferguson (2013) menjelaskan bahwa self-compassion berkaitan dengan subjective well-being. Individu yang memiliki self-compassion memiliki kepuasan hidup, memiliki lebih banyak kebahagiaan dan pengaruh positif. Selfcompassion dapat meningkatkan level subjective well-being individu serta menyebabkan individu lebih merasa aman. Self-compassion menonaktifkan sistem ancaman (terkait dengan perasaan tidak aman, defensif, dan sistem limbik) serta mengaktifkan sistem menenangkan diri (terkait dengan perasaan kelekatan aman, keamanan, dan sistem oxytocin-opiate) (Cug, 2015).

Lebih spesifik, penelitian mengenai self-compassion penyandang tunadaksa dilakukan oleh Septiyani dan Novitasari (2017) yang melaporkan bahwa remaja tunadaksa dengan tingkat self-compassion tinggi memiliki ciri lebih percaya diri dalam menghadapi lingkungannya, lebih bisa memaafkan kekurangan maupun kegagalan yang pernah dialaminya, dan memahami bahwa setiap permasalahan 
selalu terjadi dalam kehidupan tanpa terkecuali.

Stuntzner (2017) menjelaskan bahwa self-compassion dapat digunakan untuk memperkuat individu penyandang disabilitas salah satunya penyandang tunadaksa dalam proses menyesuaikan diri sesuai dengan kebutuhan mereka. Selfcompassion berfungsi mengurangi pemikiran dan perasaan negatif serta mengarahkan pada perilaku positif penyandang disabilitas. Ketika apa yang diharapkan tidak sesuai dengan rencana ia mampu menerima, sehingga dengan adanya self-compassion individu penyandang disabilitas akan mampu menerima ketidaksempurnaan yang dimiliki karena tidak ada individu yang sempurna. Hal ini membuat individu disabilitas mampu menghadapi kesulitan yang dimiliki daripada menghindari atau menyimpan dalam diri. Hal ini membantu mereka untuk menyesuaikan diri dengan pemikiran, ketidaksempurnaan ataupun pengalaman yang mereka alami dan menghadapinya dengan menenangkan diri serta menerima apa yang dialami tanpa menyakiti diri sendiri.

Al-Karimah (2018) mengemukakan bahwa penyandang tunadaksa di Balai Besar Rehabilitasi Sosial Bina Daksa (BBRSBD) telah memiliki tingkat subjective well-being tinggi. Mayoritas subjective well-being mereka tinggi ketika berada di lingkungan sosial yang mendukung dirinya seperti keluarga, bapak-ibu asuh pengganti orang tua, dan yang paling penting adalah teman-teman yang mengalami nasib serupa (Al-Karimah, 2018). Lingkungan sosial yang mendukung tersebut membuat subjek merasa nyaman, percaya diri, tidak takut ditolak oleh lingkungan sekitar karena semua manusia beragam dan memiliki kekurangan dan kelebihan tersendiri (Al-Karimah, 2018). Namun hanya ada satu subjek yang memiliki subjective well-being rendah karena merasa belum mendapat apa yang diinginkan (Al-Karimah, 2018).
Mpofu dkk. (2017) menjelaskan bahwa remaja penyandang tunadaksa yang memiliki subjective well-being ditunjukkan dengan kemampuan mengaktualisasikan diri. Mereka memiliki lokus evaluasi internal yang memadai, yaitu mereka tidak selalu harus mendapatkan persetujuan dari lingkungannya namun dapat mengetahui dan menganalisis diri sendiri sesuai standar yang ia miliki. Remaja penyandang tunadaksa juga diharapkan memiliki variasi tujuan atau sasaran yang berubah dalam hidup yaitu dapat mengaktualisasikan diri, mampu berinovasi, menunjukkan inisiatif dan mampu mengelola emosi dengan baik. Komponen utama dari kesehatan mental adalah adanya hubungan yang baik serta mampu untuk mencintai ataupun menunjukkan kasih sayang. Remaja tunadaksa yang mengaktualisasikan diri ditunjukkan dengan adanya empati dan kepedulian akan mampu memiliki hubungan pertemanan yang dalam (Diener dkk., 2009). Remaja penyandang tunadaksa yang memiliki subjective wellbeing dapat menunjukkan karakteristik utamanya yaitu aktualisasi diri, pengoptimalan fungsi dan kematangan diri sehingga mereka mampu menunjukkan penerimaan diri atau memiliki sikap positif terhadap diri (Mpofu dkk., 2017).

Berdasarkan hasil penelitian di atas, dapat diketahui bahwa self-compassion dapat menunjang subjective well-being, termasuk dengan subjek penelitian remaja penyandang tunadaksa karena dapat membuat mereka bersikap lebih baik kepada dirinya sendiri dengan menekan emosi negatif yang dirasakannya sehingga lebih mampu fokus kepada cita-cita yang diinginkan, dengan demikian tingkat subjective well-being mereka dapat meningkat pula.

\section{Simpulan}

Terdapat hubungan self-compassion dengan subjective well-being pada remaja penyandang tunadaksa. Hubungan menunjukkan arah positif, yang berarti 
semakin tinggi self-compassion pada remaja penyandang tunadaksa, semakin tinggi pula subjective well being mereka ataupun sebaliknya.

\section{Daftar Pustaka}

Al-Karimah, N. F. (2018). Subjective wellbeing pada penyandang tunadaksa. Psikosains, 13(1), 57-64.

Aminzadeh, D. M., Asmari, Y., Karimi, S., Hosiensabet, F., \& Sharifi, M. (2018). Improvement of subjective well-being in students with physical disability: Mental rehabilitation based on teaching emotion regulation skills. Journal Practice in Clinical Psychology, 6(1), $39-45$.

Atmaja, J. R. (2017). Pendidikan dan bimbingan anak berkebutuhan khusus. PT. Remaja Rosdakarya.

Aziz, S. (2014). Pendidikan seks bagi anak berkebutuhan khusus. Jurnal Kependidikan, 2(2), 182-204.

Aziz, S. (2015). Pendidikan seks anak berkebutuhan khusus. Gava Media.

Azwar, S. (2014). Reliabilitas dan validitas. Pustaka Pelajar.

Barnard, L. K., \& Curry, J. F. (2011). Selfcompassion: Conceptualizations, correlates, \& interventions. Review of General Psychology, 15(4), 289-303.

Bluth, K., \& Blanton, P. W. (2015). The influence of self-compassion on emotional well-being among early and older adolescent males and females. $J$. Posit. Psychol., 10(3), 219-230. https://doi.org/10.1080/17439760.2014 .936967

Cug, F. (2015). Self-forgiveness, selfcompassion, subjective vitality, and orientation to happiness as predictors of subjective well-being (Thesis). The Department of Educational Sciences of Middle East Technical University.

Das, K. R., \& Imon, A. H. M. R. (2016). A brief review of tests for normality. American Journal of Theoritical and Applied Statistics, 5(1), 5-12. https://doi.org/10.11648/j.ajtas.201605
01.12

Dewi, S. R., \& Hidayati, F. (2015). Selfcompassion dan altruisme pada perawat rawat inap RSUD kota Salatiga. Jurnal Empati, 4(1), 168-172.

Diener, E. D., Emmons, R. A., Larsen, R. J., \& Griffin, S. (1985). The satisfaction with life scale. Journal of Personality Assessment, 49(1).

Diener, E., Lucas, R. E., \& Oishi, S. (2002). Subjective well-being: The science of happiness and life satisfaction. Dalam C. A. Snyder \& S. J. Lopez (Edited). Handbook of positive psychology (63-73). Oxford University Press.

Diener, E. D., Wirtz, R., Biswas-Diener, R., Tov, W., Kim-Prieto, C., Choi, D., \& Oishi, S. (2009). New measures of well-being. Social Indicators Research Series, 39. Assessing well-being: The collected works of Ed Diener (p. 247266). Springer Science + Business Media. https://doi.org/10.1007/978-90481-2354-4_12

Diener, E., Lucas, R. E., \& Oishi, S. (2005). Subjective well-being: The science of happiness and life satisfaction. Dalam C. A. Snyder \& S. J. Lopez (Edited). Handbook of Positive Psychology (pp. 63-73). Oxford University Press.

Direktorat Bina Kesehatan Anak. (2014). Pedoman pelayanan kesehatan anak di sekolah luar biasa (SLB) bagi petugas kesehatan. Jakarta.

Fakhrunnisak, \& Qudsyi, H. (2015). Perbedaan subjective well-being antara guru bersertifikasi dan non sertifikasi. Jurnal RAP UNP, 6(2), 126-135.

Ghasemi, A. (2012). Normality tests for statistical analysis: A guide for nonstatisticans. Endocrinology \& Metabolism, 10. https://doi.org/10.5812/ijem.3505

Ge, J., Wu, J., Li, K., \& Zheng. (2019). Self-compassion and subjective wellbeing mediate the impact of mindfulness on balanced time 
perspective in Chinese college students. Front Psychol, 10:367. https://doi.org/10.3389/fpsyg. 2019.00367

Halim, A. R. (2015). Pengaruh selfcompassion terhadap subjective wellbeing pada mahasiswa asal luar jawa tahun pertama Universitas Negeri Semarang (Skripsi tidak diterbitkan). Universitas Negeri Semarang.

Jeon, H., Lee, K., \& Kwon, S. (2016). Investigation of the structural relationships between social support, self-compassion, and subjective wellbeing in korean elite student athletes. Sage, $\quad 0(0), \quad 1-16$. https://doi.org/10.1177/003329411665 8226.

Mangunsong, F. (2011). Psikologi dan anak berkebutuhan khusus, Jilid Kedua. LPSP3.

Mpofu, J., Sefotho, M. M., \& Maree, J. G. (2017). Psychological well-being of adolescents with physical disabilities in Zimbabwean inclusive community settings: An exploratory study. African Journal of Disability, 6:325. https://doi.org/10.4102/ajod.v6i0.325

Neff, K. D. (2015). The self-compassion scale is a valid and theoretically coherent measure of selfcompassion. Mindfulness, 7, 264-274.

Poerwanti, S. D. (2017). Pengelolaan tenaga kerja difabel untuk mewujudkan workplace inclusion. INKLUSI: Journal of Disability Studies, 4(1), 124.

Phillips, W. J., \& Ferguson, S. J. (2013). Self-compassion: A resource for positive aging. The Journals of Gerontology: Series B, 68(4), 529-539. https://doi.org/10.1093/geronb/gbs091

Ramawidjaya, N. M., \& Sartika, D. (2016). Correlation between self-compassion and psychological well-being on athlete of tunadaksa (Study on National Paralympic Committee Indonesia Athlete in Kota Bandung). Prosiding Psikologi, 2(2), 602-607.
Ratnasari, R. D., \& Sumiati, N. T. (2017). Pengaruh self-compassion, religiusitas, support group dan pendapatan terhadap subjective well-being orang tua anak tunagrahita. JP3I, I(1), 63-77.

Santrock, J. W. (2014). Psikologi pendidikan: Educational psychology (Buku 2) (Edisi 5). Salemba Humanika.

Septiyani, D. A., \& Novitasari, R. (2017). Peran self-compassion terhadap kecerdasan emosi pada remaja tunadaksa. Jurnal Indigenous, 2(1), 6776.

Stuntzner, S. (2017). Compassion and selfcompassion: Conceptualization of and application to adjustment to disability. Journal of Applied Rehabilitation Counseling, 48(2), 15-25. https://doi.org/10.1891/00472220.48.2.15

Sugiyono. (2017). Metode penelitian kuantitatif, kualitatif dan $R \& D$. Alfabeta.

Sumiati, N. T. (2018). The influence of self-compassion and coping strategies to subjective well-being of parents with intellectual disabled children. Atlantis Press, 153, 106-110.

Zessin, U., Dickhäuser, O., \& Garbade, S. (2015). The relationship between selfcompassion and well-being: A metaanalysis. Applied Psychology: Health and Well-Being, 7(3), 340-364. https://doi.org/10.1111/aphw.12051. 